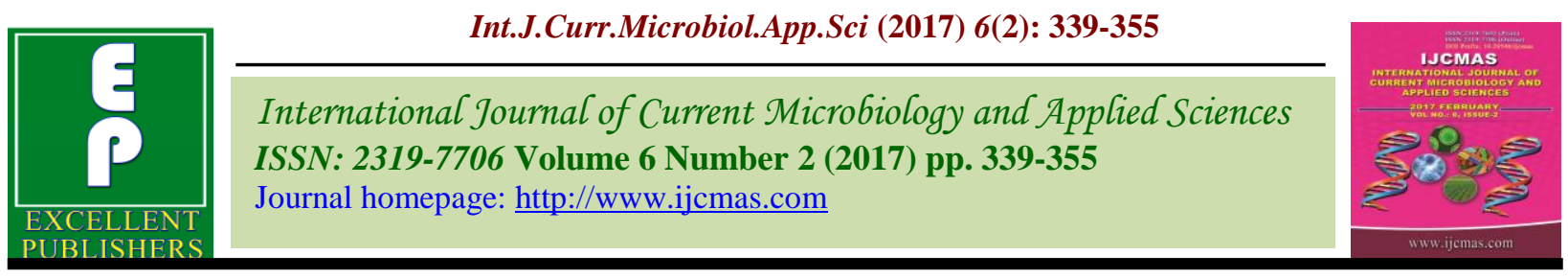

Original Research Article

http://dx.doi.org/10.20546/ijcmas.2017.602.038

\title{
Effect of Seed Rate on Yield and Quality of Fodder Sorghum (Sorghum bicolor L. Monench) Genotypes
}

\author{
Nierja Prajapati, Gajendra Singh, Pushkar Choudhary and Bhanwar Lal Jat*
}

Department of Agriculture, Bhagwant University Ajmer, Rajasthan India

*Corresponding author:

\author{
A B S T R A C T
}

\begin{tabular}{|l|}
\hline Ke y w o r d s \\
DAS, \\
NFE, \\
TDN, \\
CSV, \\
Genotype. \\
\hline Article Info \\
\hline $\begin{array}{l}\text { Accepted: } \\
\text { 12 January } 2017 \\
\text { Available Online: } \\
\text { 10 February } 2017\end{array}$ \\
\hline
\end{tabular}

The experimental soil was clay in texture, slightly alkaline in reaction, medium in available nitrogen, phosphorus and potassium. The results revealed that seed rate of $45 \mathrm{~kg} / \mathrm{ha}$ recorded maximum dry matter accumulation at 40 DAS and at harvest. The percent increase in green and dry fodder yield of this seed rate over seed rate of 30 and 35 $\mathrm{kg} / \mathrm{ha}$ were $14.21,21.91$ and $7.41,11.02$ respectively. Seed rate of $45 \mathrm{~kg} / \mathrm{ha}$ recorded significantly higher $\mathrm{N}$ and $\mathrm{P}$ uptake over 40,35 and 30 seed rate/ha but $\mathrm{N}$ and $\mathrm{P}$ content did not influence significantly by increased seed rate. Seed rate of $45 \mathrm{~kg} / \mathrm{ha}$ recorded NFE content over rest of the seed rate but found at with $40 \mathrm{~kg} / \mathrm{ha}$. The percent increase in green and dry fodder yield was of this variety CSV 28 and CSV 15 was 8.79, 10.94 and 9.80, 21.16 respectively. It was found statistically at par with CSV 23. Variety Partap Chari 1080 recorded significantly higher nitrogen content and its uptake, crude protein, mineral ash and ether extract over rest of the genotypes except genotypes' CSV 23. On the other hand variety CSV 15 recorded maximum crude fiber content, TDN and NFE. Variety Pratap Chari 1080 recorded significantly higher uptake of crude protein, crude fiber, mineral ash, ether extract, NFE and TDN over variety CSV 23, CSV28 and CSV 15.

\section{Introduction}

Livestock is the backbone of Indian economy. It plays a vital role in the rural economy of India as it supplements the family income and provides employment and thus contributes 25 $\%$ to the total agriculture income. The project shortage of dry and green fodder are 23.46 and $62.76 \%$ compared with the requirement of 589 and 1064 million tones, respectively for the current livestock population (Rai et al., 2009). Therefore to fill the supply there is need to boost up the production of green and dry fodder yields. Importance of livestock for Rajasthan can be over emphasized. Inspite of large livestock population (578.99 lakh) of state (Govt. of Rajasthan, 2008) the population of milk continues to be exceedingly low. Inadequate and poor quality feed and fodder supplied to the milch animals is the main cause of low milk production. There is an urgent need to boost the production of good quality fodder for improving the health of the vast livestock population of the state. Among fodder crops, sorghum (Sorghum bicolor L. Monench) is one of the most important one, which is largely cultivated in the country during different seasons to produce green and dry fodder. Sorghum (Sorghum bicolor L. 
Monench) is an important fodder and ration for cattle widely grown owing to its ability to grow under varying soil and agro climatic situations. As a fodder it is fast growing, palatable and nutritious. It can be utilized as hay and silage besides fresh feeding. In India 7.06 million hectare area is under this crop and the production is about 6.74 million tones with an average productivity of $956 \mathrm{~kg} / \mathrm{ha}$. In Rajasthan the area of sorghum cultivation of 6.80 lakh hectares with an annual production of $4.20 \mathrm{MT}$ and productivity of $618 \mathrm{~kg} / \mathrm{ha}$ (Agriculture Statistics, 2013). Sorghum as green fodder is very popular in western UP, Punjab, Haryana, Gujarat, and Rajasthan and in many other states. Forage sorghum is characterized by quick growth, high quality biomass accumulation and higher dry matter content. It has wide adaptability in different agro-climatic besides drought withstand ability is also suitable for silage and hay making. In Rajasthan the major sorghum growing districts are Ajmer, Pali, Kota, and Udaipur where the productivity of sorghum is very low probably due to the fact that it is mainly grown for fodder purpose and farmers pay less attention towards its scientific cultivation in general and improved genotypes as well as plant population. The production of fodder sorghum can be increased by adopting improved package of practices including suitable genotypes and plant stand. The number of plants required per unit area is one of the prime considerations for higher biomass production which depends upon the nature of the crop, growth habit and environment. Thus number of plant population can neither be too small so that all the production potential will not be utilized, nor can it be too large so that excessive plant competition will reduce the overall efficiency of the crop. Seed rate is one of the important factors in achieving optimum level of plant density, so that plant makes efficient use of resources (Mayub et al., 2002). Seed is the most important input in the fodder crop production programmes. Since most of the fodder crops production still more assumes greater importance. Seed rate in fodder crops is high but the seed multiplication ratio is low compared crops and as the fodder crops are basically bred for higher biomass production. In view of the above facts, an experiment entitled "Effect of seed rate on yield and quality of fodder sorghum (Sorghum bicolor L. Monench) genotypes" has been conducted during year 2015 at Agriculture Farm, Bhagwant University Ajmer with the following objectives: (i) To study the effect of seed rates and genotypes on productivity and quality of fodder sorghum. (ii) To work out interaction effect, if any. (iii) To access the economics of treatment.

\section{Material and Methods}

A field experiment entitled "Effect of Seed Rate on Yield and Quality of Fodder Sorghum [Sorghum bicolor (L.) Monench] genotypes" was conducted during summer 2015. The details of techniques followed and criteria adopted for treatment evaluation during the course of investigation are presented in this chapter under appropriate heads.

Experimental Site: The field experiment was carried out at the Agriculture Farm, Bhagwant University, Ajmer Rajasthan during kharif season of 2015 at an altitude of $486 \mathrm{~m}$ above sea level at $26^{\circ} 27 \mathrm{~N}$ latitude and $74^{\circ} 38 \mathrm{E}$ longitude. The region falls under agro climatic Zone III (Semi arid eastern plain).

Soil: The experimental site was fairly leveled and uniform in depth and topography. In order to know the physical- chemical properties of the experimental site, the soil samples from $30 \mathrm{~cm}$ depth were randomly collected from different locations of the experimental field before the start of the experiment and a composite sample was prepared and analyzed for physical and 
chemical properties of soil. The methods adopted to determine the important initial properties and data pertaining to them are presented in table 1 .

$\mathrm{B} / \mathrm{C}$ ratio $=\frac{\text { Net return }(\text { Rs per hecter }}{\text { Total cost }(\text { Rs per hecter }}$

Statistical analysis: The data collected during the course of present investigation were statistically analyzed by adopting standard methods known as 'Analysis of Variance' (Panse and Sukhatme, 1967). Where ever results were significant critical differences (CD) were worked out at 5 per cent level of probability for comparison of treatment mean. The treatment effects were presented by making tables of means with appropriate standard error (SE $\mathrm{m} \pm$ ) and $\mathrm{CD}$ values.

Correlation and regression studies: To assess relationship between various characters, correlation coefficients were computed. Further, in order to establish cause and effect relation, regression equation were worked out. All the statistical estimates were computed by standard statistical procedures (Panse and Sukhatma 1985).

\section{Results and Discussion}

Data were analyzed statistically to see the test of significance of the result. Analysis of variance for these data has been furnished in appendices from I to IX at the end, wherein significance at $5 \%$ level of probability has been indicated by asterisk.

Plant Population: At 15 DAS: data presented in table 2 and figure 1 show that plant height was significantly influenced by increased seed rate. Seed rate of $45 \mathrm{~kg} / \mathrm{ha}$ significantly increased plant population over $30,35 \mathrm{~kg}$ and $40 \mathrm{~kg} / \mathrm{ha}$. Seed rate of $45 \mathrm{~kg} / \mathrm{ha}$ recorded an increase in plant population by $56.81,51.06$ and $14.25 \%$ over 30,35 and 40kg/ha, respectively. The magnitude of present increase was 37.25 and 32.22 respectively. Genotype: a perusal of data presented in table 2 and figure 1 reveals that all of genotypes failed to record plant population at significant level at 15 DAS influence plant population significantly at 40 DAS.

At harvest: Seed rate: data present in table 2 and figure 1 show that plant population at harvest was significantly influence by increased seed rate. Seed rate of $45 \mathrm{~kg} / \mathrm{ha}$ registered significantly higher plant population at harvest over 30,35 and $40 \mathrm{~kg} / \mathrm{ha}$. Seed rate $45 \mathrm{~kg} / \mathrm{ha}$ recorded increase in plant population by $56.82,50.99$ and $14.38 \%$ over 30, 35 and 40kg/ha respectively. Genotypes: a perusal of data presented in table 2 reveals that all the genotypes did not influence plant population significantly at harvest.

Growth Parameters: Seed rate: data present in table 2 show that plant height was significantly influenced by increased seed rate. Seed rate of $35 \mathrm{~kg} / \mathrm{ha}$ registered significantly higher plant height at 40 DAS over $30 \mathrm{~kg} / \mathrm{ha}$ but remained at par with seed rate of $45 \mathrm{~kg} / \mathrm{ha}$. Seed rate $35 \mathrm{~kg} / \mathrm{ha}$ recorded increase in plant height by 18.94 and $7.90 \%$ over 30 and $45 \mathrm{~kg} /$ ha respectively. Genotype: Data presented in table 2 show that plant height was significantly influenced by genotypes. It is evident from the table that variety Pratap Chari 1080 registered significantly higher plant height at 40 DAS over rest of the varieties but found at par with CSV 23. Variety Partap Chari 1080 and CSV 23 both varieties were recorded increase in plant height by 15.26 and $10.01 \%$ over variety CSV 15.

Plant height at harvest: Seed rate: An examination of data reveals that $30 \mathrm{~kg} / \mathrm{ha}$ seed rate recorded significant higher plant height at harvest over $40 \mathrm{~kg}$ and $45 \mathrm{~kg} / \mathrm{ha}$ but found at 
par with $35 \mathrm{~kg} / \mathrm{ha}$. The magnitude of increase in plant height at harvests over $45 \mathrm{~kg} / \mathrm{ha}$ was 12.85 percent. Genotype: a perusal of data present in table show that PC 1080 recorded maximum plant height at harvest over rest of the genotypes tested. These genotypes recorded 18.47 and $27.07 \mathrm{~cm}$ higher in plant height at harvest over CSV 28 and CSV 15, respectively.

Stem girth at harvest: Seed rate: An examination of data depicted in table 2 show stem girth was significantly influenced by increased seed rate. Seed rate of $30 \mathrm{~kg} / \mathrm{ha}$ recorded significantly higher stem girth over seed rate 40 and $45 \mathrm{~kg} / \mathrm{ha}$ but was found at par with $30 \mathrm{~kg} / \mathrm{ha}$. The stem girth at seed rate of $30 \mathrm{~kg} / \mathrm{ha}$ recorded 10.19 and $26.60 \%$ stem girth over both the seed rate of 40 and 50kg/ha. Genotypes: An examination of data depicted in table 2 shows that stem girth at harvest is significantly influenced by genotypes. Variety CSV 23 recorded significantly higher stem girth over all the varieties under test except CSV 28. Variety CSV 28 was higher to the tune of $11.76 \%$ higher stem girth over Partap Chari 1080.

Dry Matter production: At 50 DAS: Seed rate: Data (Table 3 and figure 2) show that seed rate of $30 \mathrm{~kg} /$ ha registered significantly higher dry matter accumulation plant-1over $45 \mathrm{~kg} / \mathrm{ha}$ but was found a par with seed rate of 35 and $40 \mathrm{~kg} / \mathrm{ha}$. Seed rate $30 \mathrm{~kg} / \mathrm{ha}$ recorded increase in dry matter at this stage which was significantly higher by 10.34 percent over 45kg/ha. Genotype: - Data presented in table show that variety Partap Chari 1080 registered significantly higher dry matter accumulation plant-1 40 DAS over CSV 28 and CSV 15 but was found statistically at par with genotypes CSV 23. Variety Partap Chari 1080 recorded increase in dry matter at this stage by 15.00 and 13.59 percent over CSV 28 and CSV 15 respectively.
At harvest: Seed rate: Data presented in Table 3 shows that increased seed rate significantly influenced dry matter accumulation at harvest. Seed rate of $30 \mathrm{~kg} / \mathrm{ha}$ registered significantly higher dry matter accumulation plant ${ }^{-1}$ at harvest over the rest of treatment. Seed rate of $30 \mathrm{~kg} / \mathrm{ha}$ recorded increase in dry matter at harvest which was significantly higher by $6.03,7.53$ and 9.30 percent over the seed rate of 35,40 and $45 \mathrm{~kg} / \mathrm{ha}$ respectively. Genotypes: The perusal of data explicit that genotypes significantly influenced dry matter production at harvest. Variety Partap Chari 1080 registered significantly higher dry matter accumulation plant $^{-1}$ at harvest over verity CSV 28 and CSV 15 plant $^{-1}$ however it was found at par with CSV 23. Thus this variety increased dry matter to the tune of 10.24 and 11.84 percent over CSV 28 and CSV 15. Data further revealed that CSV 23 also recorded significantly higher dry matter accumulation at harvest over CSV 28 and CSV 15 and registering 8.98and 10.56 percent.

Leaves plant ${ }^{-1}$ at harvest: Seed rate: It is evident from data presented in table 3 that total leaves plant ${ }^{-1}$ not significantly influenced by increased seed rate. Genotypes: It is evident from data presented in table 3 that varieties significantly influenced the total leaves plant ${ }^{-1}$ at harvest. Variety Partap Chari 1080 recorded significantly more leaves over CSV 28 and was found statistically at par with CSV 23 and CSV 15. Data further explained that this variety recorded 18.34 percent higher total leaves plant ${ }^{-1}$ over variety CSV 15.

Leaf weight plant $^{-1}$ at harvest: Seed rate: Data on leaf weight plant $^{-1}$ at harvest presented in table show that at harvest it significantly influenced by increased seed rate. Seed rate of $30 \mathrm{~kg} / \mathrm{ha}$ recorded significantly at par with seed rate of $35 \mathrm{~kg} / \mathrm{ha}$. Seed rate of $30 \mathrm{~kg} / \mathrm{ha}$ recorded significantly 
increase in leaf weight plant $^{-1}$ by 5.04 and $7.73 \%$ over seed rate of 40 and $45 \mathrm{~kg} / \mathrm{ha}$. Genotype: Data of leaf weight plant ${ }^{-1}$ harvest presented in table 3 show that leaf weight plant $^{-1}$ at harvest is significantly influenced by genotypes. Variety Partap Chari1080 recorded significantly higher leaf weight plant ${ }^{-1}$ over variety CSV 28, CSV15 and was found statistically at par with genotypes CSV 23. Partap Chari 1080 recorded 22.39 percent higher leaf weight plant $^{-1}$ over CSV 15.

Leaf/Stem ratio: Seed rate: It is evident from data presented in table 3 that leaf/Stem ratio did not significantly influence by increased seed rate. Genotypes: Data on leaf/stem ratio at harvest set out in table indicate that variety Partap Chari 1080 recorded significantly higher leaf/stem over CSV 28. Data further explained variety Pratap Chari 1080 recorded 10.00 percent leaf/stem ratio at harvest over genotype CSV 28.

Fodder yield: Green fodder: Seed rate: data presented in table 4 and figure 3 revealed that green fodder yield is significantly influenced by increased seed rate. Seed rate of $45 \mathrm{~kg} / \mathrm{ha}$ recorded significantly higher green fodder yield over seed rate of 30 and $35 \mathrm{~kg} / \mathrm{ha}$ but found at par with seed rate of $40 \mathrm{~kg} / \mathrm{ha}$. Data further explicit that seed rate of $40 \mathrm{~kg} / \mathrm{ha}$ recorded $10.40 \%$ higher green fodder yield over seed rate of 30. Genotype: Data presented in table 4 reveal that green fodder yield is significantly influenced by genotypes. Variety Partap Chari 1080 recorded significantly higher green fodder yield over variety CSV 28 and CSV 15 and was found at par with variety CSV 23. Data further explicit that variety Partap Chari 1080 recorded 8.79 and 9.80 percent higher green fodder yield over varieties CSV 28 and CSV 15 respectively. Dry fodder yield Seed rate: Data presented in table 4 reveal that green fodder yield is significantly influenced by increased seed rate. Seed of $45 \mathrm{~kg} / \mathrm{ha}$ recorded significantly higher dry fodder yield $(160.35 \mathrm{q} / \mathrm{ha})$ over seed rate of 30 and $35 \mathrm{~kg} / \mathrm{ha}$ and was found at par with seed rate of $40 \mathrm{~kg} / \mathrm{ha}$. Seed rate of $40 \mathrm{~kg} / \mathrm{ha}(150.88 \mathrm{q} / \mathrm{ha})$ significantly increased dry fodder yield by 14.71 percent over seed rate of $30 \mathrm{~kg} / \mathrm{ha}$ (131.53q/ha).

Quality parameters: Crude protein content: Seed rate: Data presented in table 5 and figure 4 indicate that crude protein content was not affected significantly by increased seed rate under test. Genotypes: Data presented in table 5 indicate that crude protein content was not affected significantly higher crude protein content of fodder over test genotypes tested. Crude fiber content. Seed rate: Data presented in table 5 indicate that crude protein content was not affected significantly by increased seed rate under test. Genotypes: Data presented in table 5 indicate that crude protein content was not affected significantly crude fiber content fodder at harvest. Variety CSV 15 recorded significantly higher crude fiber compared to variety Partap Chari 1080 and followed by CSV 28 and CSV 15 recorded 5.69 percent higher crude fiber content over variety Partap Chri 1080 which recorded the lowest crude fiber (30.94\%) among all the varieties under test. Ether Extract: Seed rate-Data presented in table 5 indicate that crude protein content was not affected significantly by increased seed rate under test. Genotypes Seed rate: The variety recorded an increase in ether extract by 8.38, 5.23 and 2.84 percent over CSV 15, CSV 28 and CSV 23 respectively.

Total digestible nutrient: Seed rate: Data presented in table 5 indicate that crude protein content was not affected significantly by increased seed rate under test. Genotype: Seed rate: Data presented in table 5 indicate that maximum total digestible nutrient were recorded were recorded under variety CSV 15 . 
Production on fodder quality parameters: Crude protein-seed rate: a perusal data present in table reveals that $45 \mathrm{~kg} / \mathrm{ha}$ seed rate recorded maximum crude protein uptake and found significantly higher over 30 and $35 \mathrm{~kg} / \mathrm{ha}$. The magnitudes of increase were 18.60 and 8.70 percent, respectively. Genotypes: It can be inferred from the data (Table 6 and figure 5) that variety Partap Chari 1080 produced maximum crude protein (1330.80kg/ha) followed by genotype CSV 23 which is found at par with it. The lowest crude protein production was recorded with CSV 15 (847.44kg/ha). Variety Partap Chari 1080 recorded significantly higher crude protein production over varieties CSV 23, CSV 28 and CSV 15 by 133.13, 308.43 and $483.44 \mathrm{~kg} / \mathrm{ha}$ respectively.

Crude fiber: Seed rate: data present in table 6 reveal that $45 \mathrm{~kg} / \mathrm{ha}$ seed rate recorded 19.49 and 9.24 percent higher in crude uptake over 30 and $35 \mathrm{~kg} / \mathrm{ha}$ and this level of seed rate was found at par to $40 \mathrm{~kg} / \mathrm{ha}$. Genotype: it is evident form data presented in table 6 that varietal treatments significantly affect crude fiber production at harvest. Variety Pratap Chari 1080 recorded affect crude fiber production over CSV 28 and CSV 15. It recorded 14.50 and 6.31 percent crude fiber production over CSV 15 and CSV 28 respectively and was remain at par to CSV 23 .

Ether extract: Seed rate: data table 6 revealed that application of 40 and $45 \mathrm{~kg} / \mathrm{ha}$ seed rate recorded 11.81 and 18.57 percent higher ether extract uptake over $30 \mathrm{~kg} / \mathrm{ha}$. Genotype: variety Pratap Chari 1080 recorded maximum ether extract production $(287.38 \mathrm{~kg} / \mathrm{ha})$ followed by CSV 23 $(271.19 \mathrm{~kg} / \mathrm{ha})$ which was at par with it. Variety Partap Chari 1080 recorded significantly higher production of ether extract over CSV 15 and CSV 28 with the corresponding per cent increase of 31.65 and
17.31.

Mineral ash: it can be inferred from the data that variety Pratap Chari 1080 produced maximum mineral ash uptake $(1315.52 \mathrm{~kg} / \mathrm{ha})$ which was found significantly higher over CSV $23 \quad(1198.66 \mathrm{~kg} / \mathrm{ha}), \quad$ CSV 28 $(1062.44 \mathrm{~kg} / \mathrm{ha})$ and CSV $15(952.50 \mathrm{~kg} / \mathrm{ha})$, respectively. Seed rate: An examination of data Show that $45 \mathrm{~kg}$ seed recorded 15.34 and 7.96 percent higher in mineral ash uptake over 30 and $35 \mathrm{~kg} / \mathrm{ha}$.

NFE uptake: Seed rate: Data presented 35, 40 and $45 \mathrm{~kg} / \mathrm{ha}$ recorded $10.88,16.35$ and 25.24 percent higher NFE uptake over 30kg/ha. Genotypes: that genotype Partap Chari 1080 recorded maximum NFE production $(8031.13 \mathrm{~kg} / \mathrm{ha})$ which was closely followed by CSV $23(7925.28 \mathrm{~kg} / \mathrm{ha})$ and found at par with it. Variety Pratap Chari 1080 recorded 9.10 and 18.19 higher NFE production over CSV 28 and CSV 15 respectively.

Nitrogen and phosphorus content and uptake: $\mathrm{N}$ content: Seed rate- Data presented in table 7 and figure 6 indicate that nitrogen content was not affect significantly by increased seed rate under test. Genotypes: an examination of data presented in table 7 shows that variety Pratap Chari 1080 recorded significantly higher nitrogen content in dry fodder compared to variety CSV 23, CSV 28 and CSV 15. Variety Pratap Chari 1080 recorded 8.05, 17.20 and 29.54 percent higher nitrogen content in dry fodder over CSV 23, CSV 28 and CSV 15 respectively.

$P$ content: Seed rate- Data presented in table 7 indicate that nitrogen content was not affect significantly by increased seed rate under test. Genotypes: data presented in table reveals that variety Partap Chari 1080 recorded maximum $(0.217 \%) \mathrm{P}$ concentration in dry fodder compared to CSV 28 (0.205\%), CSV $15(0.186 \%)$ and CSV $23(0.212 \%)$. 
N uptake: Seed rate: an examination of data table 7 shows that seed rate $45 \mathrm{~kg} / \mathrm{ha}$ recorded significantly higher nitrogen uptake over rest of lower seed rates except $40 \mathrm{~kg} / \mathrm{ha}$. This seed rate recorded significantly increase in nitrogen in nitrogen uptake by dry fodder to the tune of 18.59 and 8.71 percent over 30, 30 and $35 \mathrm{~kg} / \mathrm{ha}$ respectively. Genotypes: an examination of data table 7 show that variety Partao Chari 1080 recorded significantly higher nitrogen uptake over varieties CSV 23, CSV 28 and CSV 15 and found. Varieties Partap Chari 1080 recorded significantly increase in nitrogen uptake by dry fodder to the tune of $11.11,30.17$ and 57.05 percent over varieties CSV 28 and CSV 23, respectively.

P uptake: Seed rate: A critical examination of data presented in table 7 shows that seed rate $45 \mathrm{~kg} / \mathrm{ha}$ recorded significantly maximum P Uptake (32.94kg/ha) over 30 and $35 \mathrm{~kg} / \mathrm{ha}$. Genotypes: data depicted in table 7 reveals that variety Partap Chari 1080 recorded significantly higher phosphorus uptake over CSV 28 and CSV 15 and this genotypes found remain at par with CSV 23. Data further revealed that Partap Chari 1080 and CSV 23 recorded 17.08, 41.86, 11.64 and $35.30 \%$ higher phosphorus uptake over CSV 28 and CSV 15, respectively.

Chlorophyll content: Seed rate: data present in table 8 and figure 7 indicate that chlorophyll content at 50 DAS was not influenced significantly by increased seed rate under test. Genotype: table 8 that varietal treatment significantly affected the chlorophyll content in leaves 50 DA. Data indicate further that among varieties, Partap Chari 1080 recorded the highest chlorophyll content $(2.58 \mathrm{mg} / \mathrm{g})$ in leaves to rest ones. This variety recorded higher chlorophyll content by 5.74 and 9.32 percent over variety CSV 28 and CSV 15 respectively and found at par with CSV 23 in this respect.

Economical evaluation: Net returns: Data show that seed rate of $45 \mathrm{~kg} / \mathrm{ha}$ recorded (Rs $38366 \mathrm{~kg} / \mathrm{ha}$ ) significantly higher net returns compared to seed rate of 30 (32014 Rs/ha) and $35 \mathrm{~kg} / \mathrm{ha}(34877 \mathrm{Rs} / \mathrm{ha})$ and were found statistically at par with $40 \mathrm{~kg} / \mathrm{ha}$. Seed rate of $40 \mathrm{~kg} / \mathrm{ha}$ (Rs 36679) was also found significantly superior over 30 and 35 seed rate $/ \mathrm{kg}$. The percent increase in net returns due to seed rate of $40 \mathrm{~kg} / \mathrm{ha}$ was 14.57 percent compared to seed rate of $30 \mathrm{~kg} / \mathrm{ha}$. Data further revealed that $40 \mathrm{~kg} / \mathrm{ha}$ was revealed that $40 \mathrm{~kg} / \mathrm{ha}$ was remained at par to its lower level of seed rate $35 \mathrm{~kg} / \mathrm{h}$ also. Genotypes: data table 9 show varieties Partap Chari 1080 recorded significantly higher net returns to compare to varieties CSV 28 and CSV 15 was found statistically at par with CSV 23. Genotypes CSV 23 was CSV 23 was also found significantly superior over CSV 28 and CSV 15. The percent increase in net returns due to Pratap Chari 1080 and CSV 23 was 17.04, 16.48, 16.48, 6.67 and 8.90 compared to varieties CSV 28 and CSV 15 respectively.

B/C ratio: Seed rate: data table 9 show that seed rate of 40 and $45 \mathrm{~kg} / \mathrm{ha}$ with nonsignificantly difference between these two and found significant superior over 30 and 35 $\mathrm{kg} /$ ha with respect to $\mathrm{B} / \mathrm{C}$ ratio. The highest significant $\mathrm{B} / \mathrm{C}$ ratio was obtained with seed rate of $45 \mathrm{~kg} / \mathrm{ha}(2.59)$. Seed rate $40 \mathrm{~kg} / \mathrm{ha}$ recorded 13.18 percent higher $\mathrm{B} / \mathrm{C}$ ratio over $30 \mathrm{~kg} / \mathrm{ha}$.

Genotype: data table showed that variety Pratap Chari 1080 recorded (2.69) B/C ratio which was found significantly superior over rest of the genotypes with respect to $\mathrm{B} / \mathrm{C}$ ratio of 2.47, 2.28 and 2.20 in CSV 23 CSV 28 and CSV 15, respectively.

Available nutrients harvest: Seed rate: data table 10 revealed that seed rate $30 \mathrm{~kg} / \mathrm{ha}$ 
recorded maximum $(335.46 \mathrm{~kg} / \mathrm{ha})$ potassium, however seed rate failed to recorded any significant change in nitrogen and phosphorus in soil after the harvest of the crop. Genotypes: A critical examination of the data presented in table 10 reveals that all the tested genotypes failed to record any significantly variation in nitrogen, phosphorus and potassium content in soil after the harvest of crop.

Effect of seed rate: Plant population: Plant population was significantly increased in seed rate (Table 1). It is quite obvious to obtain higher plant population at higher seed rate provided that seed have similar viability and test weight. These results confirm the finding of Ayub et al. (2007).

Growth parameters: Growth characters are controlled by the genetic make-up of the species, plant stem girth, dry matter accumulation and leaf stem ratio at 40 DAS and at harvest decreased with increased seed rate (Table 2 and 3). Plant height sown at seed rate of $30 \mathrm{~kg} / \mathrm{ha}$ produce significantly taller than 40 and $45 \mathrm{~kg} / \mathrm{ha}$ by 7.08 and 12.85 percent but at par with $35 \mathrm{~kg} / \mathrm{ha}$ at harvest (Table 2). This may be due to positive effect of increased plant height with reduced seed rate mainly due to competition for light. These results confirm the finding of Ayub et al. (2007), Osman et al. (2010) and Mahdi et al. (2011). Stem diameter significantly decreased with increased seed rate (Table 2). The maximum $(1.19 \mathrm{~cm})$ and minimum $(0.94 \mathrm{~cm})$ stem diameter recorded at seed rate of $30 \mathrm{~kg} / \mathrm{ha}$ and $45 \mathrm{~kg} / \mathrm{ha}$ of seed rate. This may be due to severe competition to sorghum plants for nutrients, sun light and moisture. These results confirm the finding of Ayub et al. (2007), Osman et al. (2010) and Mahdi et al. (2011).It was also found that leaf/stem ratio decreased with increased seed rate.
(Table 3) however, difference was not significant, which may be attributed to increased higher of the plant at higher plant density. These results confirm the finding of Mahdi et al. (2011).

Yield attributes and yield: Seed rate had significant effect on yield potential (Table 4) high seed rate to produce higher fodder yield. The seed rate of $40 \mathrm{~kg} / \mathrm{ha}$ by 10.40 and 3.82 percent possible effect of increased yield with seed rate mainly due to more plant density viz more plant height and more functional leaves per unit area. Further dry matter production is related to the amount of solar radiation intercepted by the canopy. Increase in yield with increased seed rate has also been reported by Ayub et al. (2007).

Nutrient content and uptake: The nutrient content in fodder at harvest non-significantly but decreased with increased seed rate (Table 6). The improvement in nutrient status of plant under seed rate might be due to their genetic makeup. It is generally believed that in plant extracted nutrients are used for maintaining their critical concentration that can be used for plant growth or development structure. The result are in close conformity with finding of Osman et al.(2010).

Quality parameter: The maximum $(32.03 \%)$ and minimum $(31.42 \%)$ crude fiber contents were noted at seed rate of $30 \mathrm{~kg} / \mathrm{ha}$ and $45 \mathrm{~kg} / \mathrm{ha}$ respectively. Non significant effect of seed rate on crude fiber has also confirm the finding of Ayub et al. (2007). The effect of seed rate on crude protein, either extract, TND contents was not significant but nitrogen free extract significant increased with increase seed rate. These results confirm the finding of Ayub et al. (2007), Osman et al. (2010) and Mahdi et al. (2011). 
Table.1 Physical-chemical properties of soil

\begin{tabular}{|c|c|c|c|}
\hline S.No & Particulars & Value & Methods adopted \\
\hline \multicolumn{4}{|c|}{ A. Mechanical analysis } \\
\hline 1 & Sand \% & 40.3 & \multirow{4}{*}{ Bouyoucos hydrometer Method (Piper, 1966) } \\
\hline 2 & Fine sand \% & 63.72 & \\
\hline 3 & Silt \% & 28.4 & \\
\hline 4 & Clay \% & 31.3 & \\
\hline 5 & Textural class & $\begin{array}{l}\text { Loam } \\
\text { Sand }\end{array}$ & Textural triangle \\
\hline \multicolumn{4}{|c|}{ B. $\quad$ Physical composition } \\
\hline 1 & Bulk density $\left(\mathrm{mg} \mathrm{m}^{-3}\right)$ & 1.36 & Core sampler method (piper 1950) \\
\hline 2 & Particle density $\left(\mathrm{mg} \mathrm{m}^{-3}\right)$ & 2.75 & Black (1965) \\
\hline 3 & Porosity $(\%)$ & 49.15 & Black (1965) \\
\hline \multicolumn{4}{|r|}{ C. Chemical analysis } \\
\hline 1 & Soil pH & 7.8 & Beckman's glass electrode, pH meter (Jackson, 1967) \\
\hline 2 & $\begin{array}{c}\text { Electrical conductivity } \\
\left(\mathrm{dSm}^{-1}\right)\end{array}$ & 0.88 & $\begin{array}{l}\text { 1:2.5 Soil Water Suspension using Electrical Conductivity } \\
\text { meter (Jackson,1967) }\end{array}$ \\
\hline 3 & Organic carbon $\%$ & 0.84 & Wet oxidation Walkley and Black method (Jackson, 1967) \\
\hline 4 & Available nitrogen $\left(\mathrm{kg} \mathrm{ha}^{-1}\right)$ & 295.3 & Alkaline permanganate method (Subbiah and Asija, 1956) \\
\hline 5 & $\begin{array}{l}\text { Available phosphorus }(\mathrm{kg} \\
\left.\text { ha }^{-1}\right)\end{array}$ & 22.5 & Olsen's method (Watanabe and Olsen, 1965) \\
\hline 6 & $\begin{array}{l}\text { Available potassium }(\mathrm{kg} \mathrm{ha} \\
\left.{ }^{1}\right)\end{array}$ & 342.8 & $\begin{array}{l}\text { Neutral } \underline{\mathrm{N}} \text { Ammonium Acetate extract using Flame } \\
\text { photometer(Hanway and Heidel 1952) }\end{array}$ \\
\hline
\end{tabular}

\begin{tabular}{|ll|lll|}
\hline \multicolumn{4}{|c|}{ Treatment details } \\
\hline A. Seed rate $(\mathrm{kg} / \mathrm{ha})$ & \multicolumn{3}{|l|}{ B. Genotypes } \\
\hline $\mathrm{S}_{1}-30$ & $\mathrm{~V}_{1}$ & - & PARTAP CHARI 1080 \\
\hline $\mathrm{S}_{2}-35$ & $\mathrm{~V}_{2}$ & - & CSV 23 \\
\hline $\mathrm{S}_{3}-40$ & $\mathrm{~V}_{3}$ & - & CSV 28 \\
\hline $\mathrm{S}_{4}-45$ & $\mathrm{~V}_{4}$ & - & CSV 15 \\
\hline
\end{tabular}

\begin{tabular}{|l|l|}
\hline \multicolumn{2}{|c|}{ Other experimental details } \\
\hline Total Number of treatment -16 & Test crop and variety - As per treatment \\
\hline Number of replication -3 & Spacing $-45 \mathrm{~cm} \times 15 \mathrm{~cm}$ \\
\hline Total number of plots -48 & Seed rate - as per treatment \\
\hline Experimental Design - Factorial RBD & Fertilizers and manures $-80 \mathrm{~kg} \mathrm{~N}, 40 \mathrm{~kg}$ P $/ \mathrm{ha}$ \\
\hline Plot Size: (i) Gross $-5.0 \mathrm{~m} \times 4.5 \mathrm{~m}=22.5 \mathrm{~m} . \mathrm{sq}$ (ii) Net $-4.4 \mathrm{~m} \times 3.6 \mathrm{~m}=15.84 \mathrm{~m} . \mathrm{sq}$ \\
\hline
\end{tabular}

\begin{tabular}{|l|l|l|}
\hline \multicolumn{2}{|c|}{ Treatment evaluation } \\
\hline Plant stand & Leaves per plant & Dry fodder yield at harvest \\
\hline Plant height & Leaf weight plant & Total chlorophyll content of leaves at 55 DAS \\
\hline Stem girth & Leaf stem ratio & Fodder Quality Parameter \\
\hline Dry matter production & Green fodder yield at harvest & Nutrient content and Uptake \\
\hline \multicolumn{2}{|c|}{ Economical Analysis } \\
\hline
\end{tabular}


Table.2 and Fig. 1 Effect of seed rate and genotypes on plant population, height and stem girth

\begin{tabular}{|c|c|c|c|c|c|}
\hline \multicolumn{3}{|c|}{ Treatment Plant Population } & \multicolumn{2}{|c|}{ Plant height (cm) } & \multirow[t]{2}{*}{ Stem girth at harvest } \\
\hline & 15 DAS & At harvest & 40 DAS & At harvest & \\
\hline \multicolumn{6}{|c|}{ Seed rate $(\mathrm{kg} / \mathrm{ha})$} \\
\hline 30 & 23.62 & 22.85 & 50.20 & 212.21 & 1.19 \\
\hline 35 & 24.52 & 23.65 & 53.67 & 209.08 & 1.17 \\
\hline 40 & 32.42 & 31.22 & 57.32 & 198.17 & 1.08 \\
\hline 45 & 37.02 & 35.71 & 57.91 & 188.05 & 0.94 \\
\hline SEm \pm & 0.80 & 0.75 & 1.01 & 3.98 & 0.03 \\
\hline C.D 5\% & 2.31 & 2.18 & 2.91 & 11.50 & 0.09 \\
\hline \multicolumn{6}{|l|}{ Variety } \\
\hline PC1080 & 29.37 & 28.30 & 58.52 & 216.57 & 1.02 \\
\hline CSV23 & 29.37 & 28.35 & 55.85 & 203.33 & 1.14 \\
\hline CSV28 & 29.32 & 28.25 & 53.96 & 198.10 & 1.11 \\
\hline CSV15 & 29.55 & 28.53 & 50.77 & 189.50 & 1.09 \\
\hline SEm \pm & 0.80 & 0.75 & 1.01 & 3.98 & 0.03 \\
\hline C.D 5\% & NS & NS & 2.91 & 11.50 & 0.09 \\
\hline
\end{tabular}

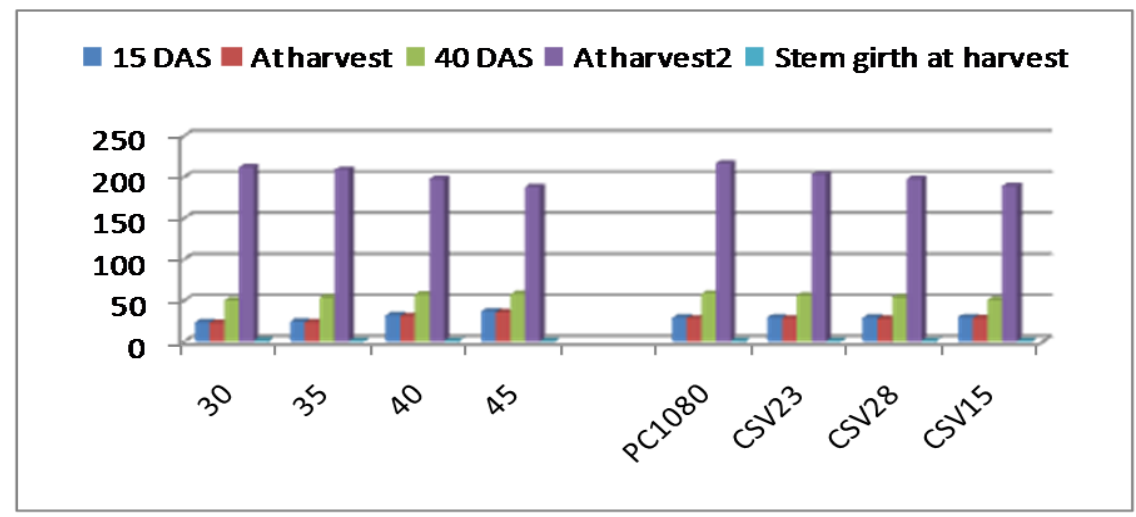

Table.3 and Fig.2 Effect of seed rate and genotype on DMA, Leaves leaf weight and leaf stem ratio

\begin{tabular}{|c|c|c|c|c|c|}
\hline \multirow[t]{2}{*}{ Treatment } & \multicolumn{2}{|c|}{$\begin{array}{c}\text { Dry matter } \\
\text { accumulation (gm) }\end{array}$} & \multirow[t]{2}{*}{$\begin{array}{l}\text { Leaves } \\
\text { plant }\end{array}$} & \multirow{2}{*}{\begin{tabular}{|l} 
Leaf \\
weight \\
(g/plant)
\end{tabular}} & \multirow{2}{*}{$\begin{array}{l}\text { Leaf } \\
\text { stem } \\
\text { ratio }\end{array}$} \\
\hline & 50 DAS & At harvest & & & \\
\hline \multicolumn{6}{|c|}{ Seed rate $(\mathrm{kg} / \mathrm{ha})$} \\
\hline 30 & 16.22 & 133.50 & 10.64 & 46.29 & 0.37 \\
\hline 35 & 15.42 & 125.72 & 11.28 & 44.80 & 0.39 \\
\hline 40 & 15.28 & 123.97 & 11.55 & 44.07 & 0.38 \\
\hline 45 & 14.70 & 121.96 & 11.63 & 42.97 & 0.38 \\
\hline SEm \pm & 0.32 & 2.36 & 0.25 & 0.65 & 0.01 \\
\hline C.D 5\% & 0.92 & 6.83 & NS & 1.87 & NS \\
\hline \multicolumn{6}{|l|}{ Variety } \\
\hline PC1080 & 16.63 & 133.24 & 12.13 & 47.56 & 0.40 \\
\hline CSV23 & 15.88 & 131.71 & 11.63 & 46.93 & 0.38 \\
\hline CSV28 & 14.46 & 120.86 & 11.08 & 44.79 & 0.36 \\
\hline CSV15 & 14.64 & 119.13 & 10.25 & 38.86 & 0.38 \\
\hline SEm \pm & 0.32 & 2.36 & 0.25 & 0.65 & 0.01 \\
\hline C.D 5\% & 0.92 & 6.83 & 0.78 & 1.87 & 0.03 \\
\hline
\end{tabular}




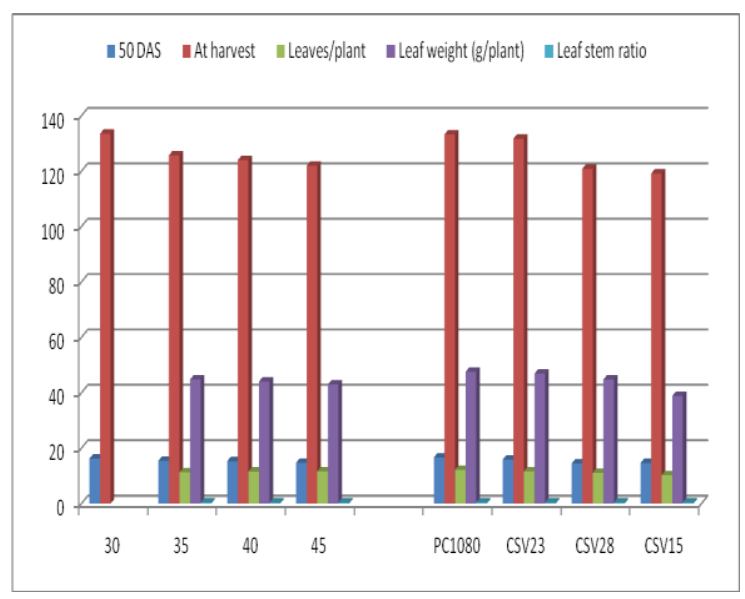

Table.4 and Fig.3 Effect of seed rate and genotype on fodder yield

\begin{tabular}{|l|c|c|}
\hline \multirow{2}{*}{ Treatment } & \multicolumn{2}{|c|}{ Yield (q/ha) } \\
\cline { 2 - 3 } & $\begin{array}{c}\text { Green } \\
\text { fodder } \\
\text { Seed rate (kg/ha) }\end{array}$ \\
\hline \multicolumn{3}{|c|}{ Dry fodder } \\
\hline 30 & 372.85 & 131.53 \\
\hline 35 & 396.47 & 144.43 \\
\hline 40 & 411.61 & 150.88 \\
\hline 45 & 425.83 & 160.35 \\
\hline SEm \pm & 9.03 & 3.89 \\
\hline C.D 5\% & 26.08 & 11.23 \\
\hline \multicolumn{3}{|c|}{ Variety } \\
\hline PC1080 & 424.27 & 158.71 \\
\hline CSV23 & 406.09 & 154.43 \\
\hline CSV28 & 389.99 & 143.06 \\
\hline CSV15 & 386.40 & 130.99 \\
\hline SEm \pm & 9.03 & 3.89 \\
\hline C.D 5\% & 26.08 & 11.23 \\
\hline
\end{tabular}

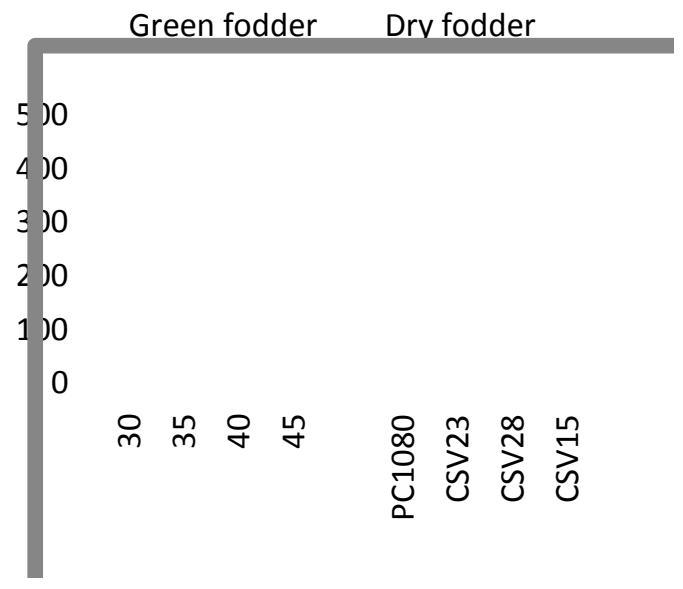


Table.5 and Fig.4 Effect of seed rate and genotypes of quality parameters at harvest

\begin{tabular}{|l|c|c|c|c|c|c|}
\hline \multirow{2}{*}{ Treatment } & \multicolumn{7}{c|}{ Quality parameters (\%) } \\
\cline { 2 - 7 } & CP & CF & EE & MA & NFE & TDN \\
\hline \multicolumn{7}{|c|}{ Seed rate (kg/ha) } \\
\hline 30 & 7.57 & 32.03 & 1.77 & 8.00 & 50.63 & 56.59 \\
\hline 35 & 7.50 & 31.95 & 1.73 & 7.68 & 51.13 & 56.73 \\
\hline 40 & 7.37 & 31.93 & 1.73 & 7.63 & 51.34 & 56.77 \\
\hline 45 & 7.33 & 31.42 & 1.72 & 7.51 & 52.02 & 56.85 \\
\hline SEm \pm & 0.07 & 0.25 & 0.02 & 0.12 & 0.29 & 0.08 \\
\hline C.D 5\% & NS & NS & NS & NS & 0.85 & NS \\
\hline \multicolumn{7}{|l|}{ Variety } \\
\hline PC1080 & 8.38 & 30.94 & 1.81 & 8.30 & 50.57 & 56.36 \\
\hline CSV23 & 7.77 & 31.40 & 1.76 & 7.80 & 51.28 & 56.66 \\
\hline CSV28 & 7.16 & 32.29 & 1.72 & 7.44 & 51.40 & 56.90 \\
\hline CSV15 & 6.47 & 32.70 & 1.67 & 7.29 & 51.87 & 57.02 \\
\hline SEm \pm & 0.07 & 0.24 & 0.02 & 0.12 & 0.29 & 0.08 \\
\hline C.D 5\% & 0.20 & 0.69 & 0.05 & 0.36 & 0.85 & 0.24 \\
\hline
\end{tabular}

CP CF EE MA NFE TDN

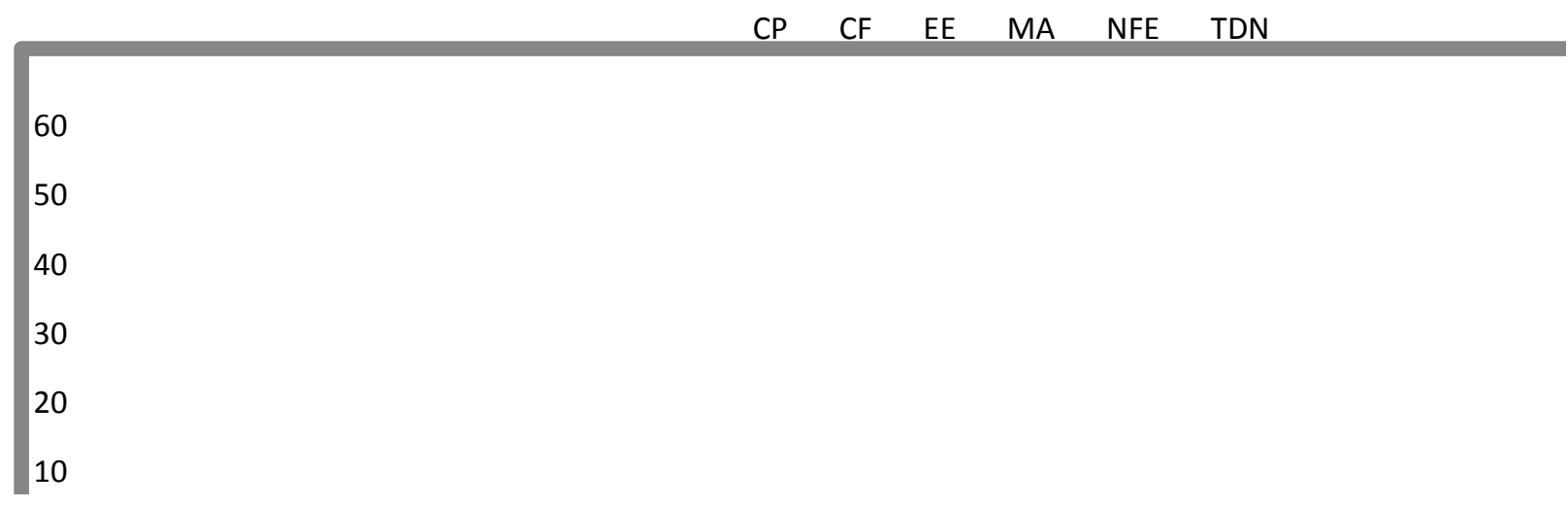

Table.6 and Fig.5 Effect of seed rate and genotypes on uptake of quality parameters at harvest

\begin{tabular}{|l|c|c|c|c|c|c|}
\hline \multirow{2}{*}{ Treatment } & \multicolumn{7}{|c|}{ Quality parameters (\%) } \\
\cline { 2 - 7 } & CP & CF & EE & MA & NFE & TDN \\
\hline \multicolumn{7}{|c|}{ Seed rate (kg/ha) } \\
\hline 30 & 1000.29 & 4210.76 & 233.44 & 1053.63 & 6654.91 & 7442.66 \\
\hline 35 & 1091.33 & 4605.65 & 250.56 & 1115.90 & 7379.34 & 8188.87 \\
\hline 40 & 1120.59 & 4808.32 & 261.02 & 1154.89 & 7743.34 & 8563.12 \\
\hline 45 & 1186.31 & 5031.37 & 276.80 & 1204.70 & 8335.39 & 9114.52 \\
\hline SEm \pm & 28.70 & 132.38 & 7.03 & 31.29 & 209.35 & 224.29 \\
\hline C.D 5\% & 83.70 & 382.33 & 20.31 & 90.38 & 640.65 & 647.81 \\
\hline \multicolumn{7}{|c|}{ Variety } \\
\hline PC1080 & 1330.88 & 4906.46 & 287.38 & 1315.52 & 8031.13 & 8945.68 \\
\hline CSV23 & 1197.75 & 4849.62 & 271.38 & 1198.66 & 7925.28 & 8753.63 \\
\hline CSV28 & 1022.45 & 4615.04 & 244.97 & 1062.44 & 7360.95 & 8140.50 \\
\hline CSV15 & 847.44 & 4284.98 & 218.29 & 952.44 & 6795.34 & 7460.36 \\
\hline SEm \pm & 22.98 & 132.38 & 7.03 & 31.29 & 209.35 & 224.29 \\
\hline C.D 5\% & 83.70 & 382.33 & 20.31 & 90.38 & 604.65 & 647.81 \\
\hline
\end{tabular}




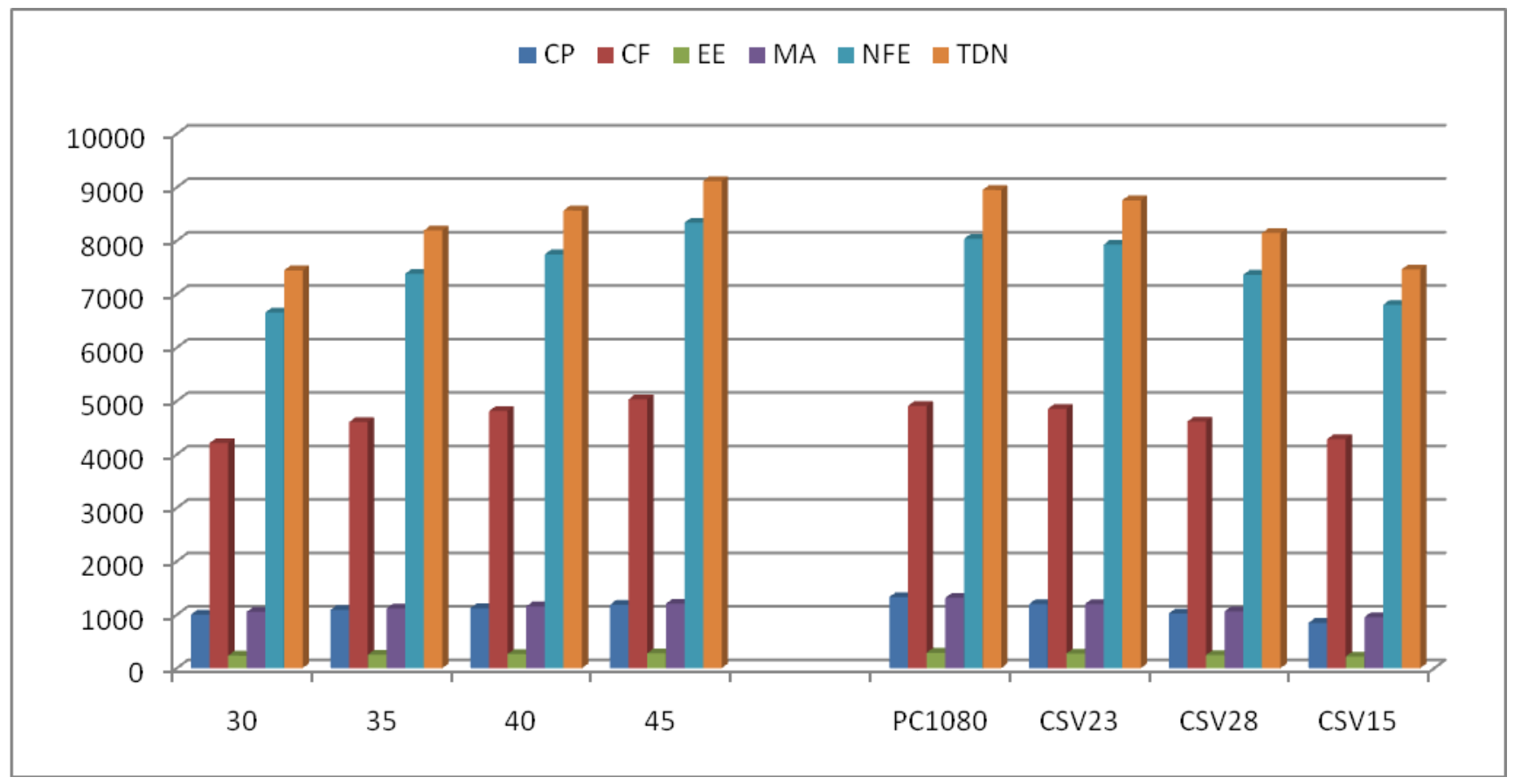

Table.7 and Fig.6 Effect of seed rate and genotypes on nutrient content and Uptake at harvest

\begin{tabular}{|c|c|c|c|c|}
\hline \multirow[t]{2}{*}{ Treatment } & \multicolumn{2}{|c|}{ Nutrient content (\%) } & \multicolumn{2}{|c|}{ Nutrient Uptake (kg/ha) } \\
\hline & $\mathbf{N}$ & $\mathbf{P}$ & 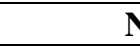 & $\mathbf{P}$ \\
\hline \multicolumn{5}{|c|}{ Seed rate $(\mathrm{kg} / \mathrm{ha})$} \\
\hline 30 & 1.121 & 0.206 & 160.05 & 27.14 \\
\hline 35 & 1.200 & 0.205 & 174.61 & 29.77 \\
\hline 40 & 1.180 & 0.205 & 179.29 & 31.00 \\
\hline 45 & 1.173 & 0.205 & 189.81 & 32.94 \\
\hline SEm \pm & 0.011 & 0.002 & 4.64 & 0.73 \\
\hline C.D 5\% & NS & NS & 13.39 & 2.12 \\
\hline \multicolumn{5}{|c|}{ Variety } \\
\hline PC1080 & 1.342 & 0.217 & 212.94 & 34.40 \\
\hline CSV23 & 1.242 & 0.212 & 191.64 & 32.81 \\
\hline CSV28 & 1.145 & 0.205 & 163.59 & 29.39 \\
\hline CSV15 & 1.036 & 01.86 & 135.59 & 24.25 \\
\hline SEm \pm & 0.011 & 0.002 & 4.64 & 0.73 \\
\hline C.D 5\% & 0.032 & 0.006 & 13.39 & 2.12 \\
\hline
\end{tabular}




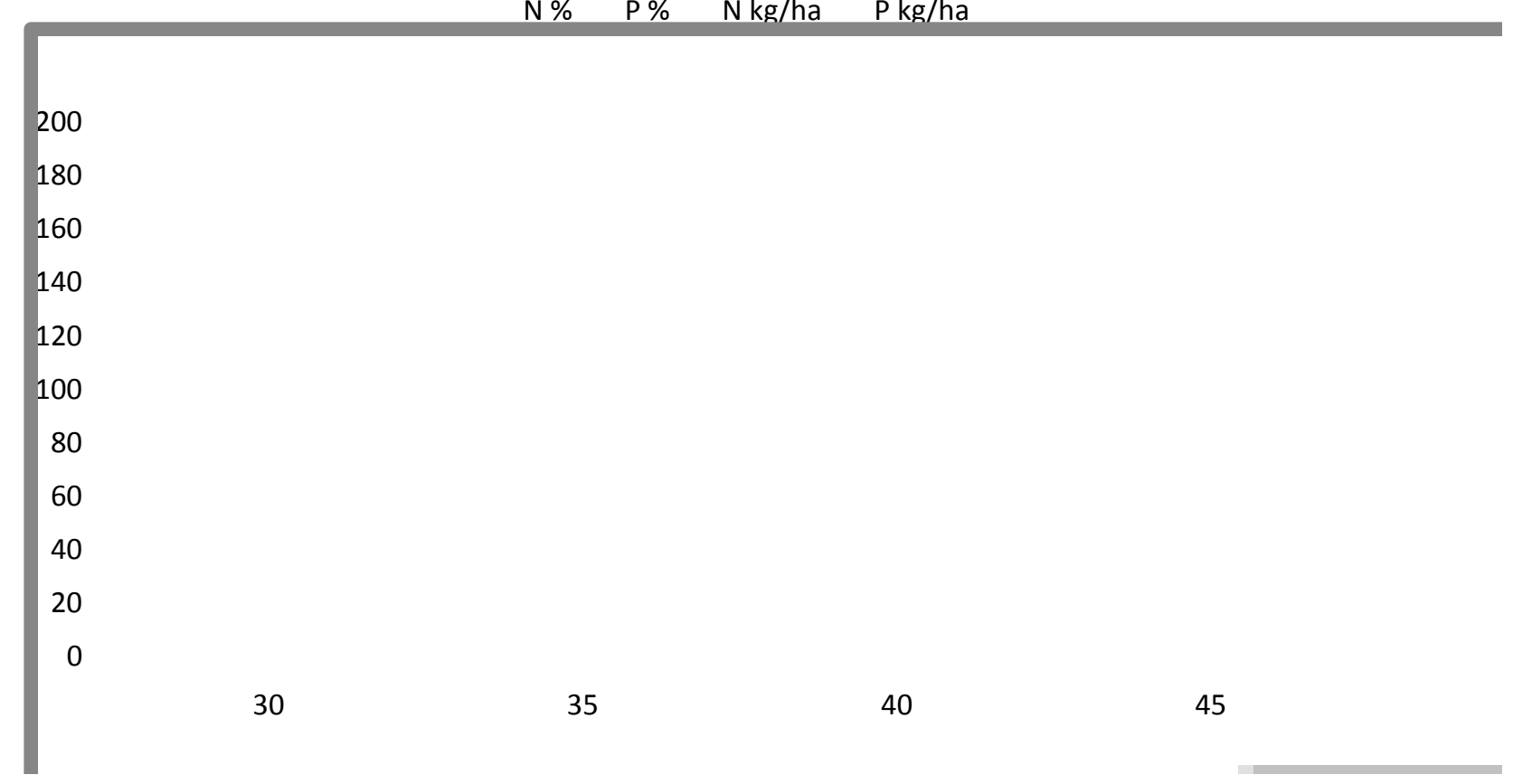

Table.8 and Fig.7 Effect of seed rate and genotypes on chlorophyll content in leaves at 50 DAS

\begin{tabular}{|l|c|}
\hline \multicolumn{1}{|c|}{ Treatment } & Chlorophyll content \% \\
\hline \multicolumn{2}{|c|}{ Seed rate (kg/ha) } \\
\hline 30 & 2.54 \\
\hline 35 & 2.47 \\
\hline 40 & 2.46 \\
\hline 45 & 2.47 \\
\hline SEm \pm & 0.04 \\
\hline C.D 5\% & NS \\
\hline \multicolumn{2}{|c|}{ Variety } \\
\hline PC1080 & 2.58 \\
\hline CSV23 & 2.56 \\
\hline CSV28 & 2.44 \\
\hline CSV15 & 2.36 \\
\hline SEm \pm & 0.04 \\
\hline C.D 5\% & 0.11 \\
\hline
\end{tabular}




\section{Cinioropinyil content \%}

2.6

2.55

2.5

2.45

2.4

2.35

2.3

Table.9 Effect of seed rate and genotype on net returns and $\mathrm{B} / \mathrm{C}$ ratio.

\begin{tabular}{|c|c|c|}
\hline Treatment & Net returns (Rs/ha) & $\mathrm{B} / \mathrm{C}$ ratio \\
\hline \multicolumn{3}{|c|}{ Seed rate $(\mathrm{kg} / \mathrm{ha})$} \\
\hline 30 & 33075 & 1.92 \\
\hline 35 & 36154 & 2.08 \\
\hline 40 & 33087 & 2.18 \\
\hline 45 & 39896 & 2.27 \\
\hline SEm \pm & 1219 & 0.07 \\
\hline C.D 5\% & 3520 & 0.20 \\
\hline \multicolumn{3}{|c|}{ Variety } \\
\hline PC1080 & 39852 & 2.29 \\
\hline CSV23 & 37397 & 2.15 \\
\hline CSV28 & 35224 & 2.02 \\
\hline CSV15 & 34739 & 1.99 \\
\hline SEm \pm & 1219 & 0.07 \\
\hline C.D 5\% & 3520 & 0.20 \\
\hline
\end{tabular}

Table.10 Effect of seed rate and genotypes on available nutrient status of soil after the harvest of crop.

\begin{tabular}{|l|c|c|c|}
\hline \multirow{2}{*}{ Treatment } & \multicolumn{3}{|c|}{ Soil available nutrient (kg/ha) } \\
\cline { 2 - 4 } & \multicolumn{3}{|c|}{ Seed rate (kg/ha) } \\
\hline \multicolumn{3}{|c|}{$\mathbf{P}$} \\
\hline 30 & 286.85 & 23.11 & $\mathbf{K}$ \\
\hline 35 & 285.73 & 23.01 & 293.96 \\
\hline 40 & 271.67 & 22.73 & 278.73 \\
\hline 45 & 271.40 & 22.71 & 278.19 \\
\hline SEm \pm & 5.15 & 0.40 & 5.03 \\
\hline C.D 5\% & NS & NS & 14.54 \\
\hline \multicolumn{3}{|c|}{ Variety } \\
\hline PC1080 & 271.29 & 22.28 & 278.08 \\
\hline CSV23 & 277.72 & 22.80 & 284.71 \\
\hline CSV28 & 282.24 & 23.15 & 289.18 \\
\hline CSV15 & 284.40 & 23.33 & 291.38 \\
\hline SEm \pm & 5.15 & 0.40 & 5.03 \\
\hline C.D 5\% & NS & NS & NS \\
\hline
\end{tabular}




\section{Effect of genotypes: Growth parameter}

The differential behavior of sorghum varieties with respect to these growth parameter could be explained solely by the variation in their genetic makeup, difference in their genotypes potential and adaptability of soil and climatic conditions. It seems that production of drier matter/plant at different growth stages of crop in variety Pratap Chari 1080 compared to CSV 15, CSV 23 and CSV 28 might be due to fact that this variety could have generated more photosynthetic site compared to other which in general and at harvest in particular. A significant and positive correlation between dry matter accumulation at harvest and plant height and plant height $(\mathrm{r}=0.783 * *)$. The results so obtained are in close conformity with finding of Meena and Mann (2007).

Fodder yield: The higher green and dry fodder yield registered by varieties Partap Chari 1080 and CSV 23 over varieties CSV 28 and CSV 15 appears to be a resultant of remarkable improvement in plant height, leaves/plant, leaf weight /plant, dry matter accumulation and leaf/stem ratio. Improvement in fodder yield is reflected by a strong positive correlation between green fodder, total leasves $\left(\mathrm{r}=0.756^{*}\right)$, which was brought about due to adoption of theses varieties. The result of obtained corroborate with the finding of Ammaji and Suryanarayan (2003), Singh and Sumeriya (2004). Nitrogen content and uptake: Genotypes variation in $\mathrm{N}$ and $\mathrm{P}$ uptake by $\mathrm{O}$ fodder crop was significantly affected due to varieties. The result indicated that Pratap Chari 1080 with non-significant difference between varieties CSV 23 recorded the highest nitrogen and phosphorus uptake compared to varieties CSV 28 and CSV 25 which might be ascribed to higher dry fodder yield with these varieties. As the uptake of nitrogen and phosphorus is mainly the function of dry fodder and nitrogen content in the fodder. A strong positive correlation of dry fodder yield with nitrogen and phosphorus uptake with corresponding ' $r$ ' value as $0.902 * *$ and $0.947^{*} *$ further substantiate the fact. The result corroborate with the finding of Gupta et al. (2002) and Rathode et al. (2005).

Quality parameters: As described in the preceding chapters it was clear that variety Partap Chari 1080 recorded maximum crude protein content, ether extract, and mineral ash over rest of the varieties under (table) Test fet alfzwhile variety CSV 15 recorded maximum crude and maximum TDN and NFE compared to othzer varieties. It was assumed that the nutritional values of the fodder are also influenced with the varieties. These results are in close agreement with the finding of Rathode et al. (2005). On the basis of one year of field it may be concluded that sowing of single cut fodder sorghum at $40 \mathrm{~kg} / \mathrm{ha}$ seed rate recorded comparable green fodder $(411.61 \mathrm{q} / \mathrm{ha})$, dry fodder $(150.88 \mathrm{q} / \mathrm{ha})$, net returns (Rs 38087 per hectare) and fetched $\mathrm{B} / \mathrm{C}$ ratio of 2.18. Among varieties Partap Chari 1080 recorded maximum green fodder (424.27 q/ha), dry fodder (158.71q/ha), net returns (Rs 39852 per hectare) and fetched $\mathrm{B} / \mathrm{C}$ ratio of 2.29 , which was closely followed by CSV 23 which realized green fodder (406.09q/ha), dry fodder (154.43q/ha), net returns (Rs 37397 per hectare) and fetched $\mathrm{B} / \mathrm{C}$ ratio of 2.15 . However, these results are only indicated and need further experimentation to reach at more consistent and definite conclusion.

\section{References}

Agrawal, D. 2009. Forage yield and quality of multicut sorghum [sorghum bicolor (L.)Moench] varieties under varying nitrogen levels. M.Sc. Thesis, Department of Agronomy, Rajasthan College of agriculture, MPUAT, Udaipur.

AICSIP. 2011. Annual progress Report 20102011. All India Coordinated sorghum 
Improvement Project, Rajasthan college of Agriculture, Udaipur.

Ammaji, P. and Suryanarayan, K. 2003. Response of fodder sorghum varieties to different levels of nitrogen. J. Res., ANGRAU, 31: 109-112.

Ayub, M., Muhammad, A.N., Tanveer, A. and Husain, A. 2002. Effect of different level of nitrogen and harvesting time on the growth, yield and quality of sorghum fodder. Asian J. Plant Sci., 1: 304-307.

Bishnoi, N.R., Mail, A.L and Sumeriya, H.K. 2003. Effect of plant population and nitrogen level on content and uptake of nitrogen and economics of dual purpose sozrghum genotypes. Agronomy digests, 3: 28-29.

Buladk, L. 2010. Effect of nitrogen levels on yield and $\mathrm{HCN}$ content of multicut forage sorghum genotypes. M.Sc thesis Department of Agronomy, Rajasthan collage of Agriculture MPUAT Udaipur

Dixit, A.K., Singh, O.P., Kachroo, D. and Amarjit, S.B 2005. Response of promising rainy season sorghum genotypes to nitrogen and phosphorus fertilization. Indian $J$. Agronomy, 50: 206-209.
Gupta, S.K., Verma, M.L and Jaiswal, R.S. 2002. Nutritional evaluation of multicut sorghum strains. Indian J. Animal Nutri., 19: 129134.

Malik, M.F., Husain M. and Awan S.I. 2007. Yield response of fodder sorghum to seed rate and row rate and row spacing under rain fed condition. J. Agri. Sci., 72: 648650.

Meena, L.R. and Mann, J.S. 2007. Response of forage sorghum (Sorghum bicolor) varieties to different levels of nitrogen with and without farmyard manure in semiarid region. Int. J. Trop. Agri., 25: 105-109.

Osman, S., Abdelsanlam, Y. and Abdesalam, K. 2010. Effect of nitrogen and seed rate on growth and yield of forage sorghum. Soudan J. Sci. Technol., 11: 123-135.

Rathode, R.A., Thokal., M.R and Khandare, N.O. 2005. Nutritive value of some sorghum fodder varieties. Annals of Plant Physiol., 19: 254-256.

Singh, P., Sumeriya, H.K., Sharma, V. and Chhipa, K.G. 2008. Study on effect of integrated nutrient management on promising genotype SU 1080. Int. J. Agri., 26: 65-67.

\section{How to cite this article:}

Pushkar Choudhary, Gajendra Singh, Nierja Prajapati and Bhanwar Lal Jat. 2017. Effect of Seed Rate on Yield and Quality of Fodder Sorghum (Sorghum bicolor L. Monench) Genotypes. Int.J.Curr.Microbiol.App.Sci. 6(2): 339-355. doi: http://dx.doi.org/10.20546/ijcmas.2017.602.038 